\title{
An unusual new species of Trechona (Araneae: Mygalomorphae: Dipluridae), from quartzitic caves of the Diamantina Plateau, Minas Gerais, Brazil, with a key to the known species
}

José Paulo L. Guadanucci, Rafael Fonseca-Ferreira, Renner Luiz Cerqueira Baptista \& Denis Rafael Pedroso

To cite this article: José Paulo L. Guadanucci, Rafael Fonseca-Ferreira, Renner Luiz Cerqueira Baptista \& Denis Rafael Pedroso (2016) An unusual new species of Trechona (Araneae: Mygalomorphae: Dipluridae), from quartzitic caves of the Diamantina Plateau, Minas Gerais, Brazil, with a key to the known species, Journal of Natural History, 50:39-40, 2487-2497, DOI: 10.1080/00222933.2016.1193652

To link to this article: https://doi.org/10.1080/00222933.2016.1193652

$$
\text { 册 Published online: } 08 \text { Jul } 2016 .
$$

Submit your article to this journal

Џ Article views: 127

View Crossmark data ¿

Citing articles: 4 View citing articles $\square$ 


\title{
An unusual new species of Trechona (Araneae: Mygalomorphae: Dipluridae), from quartzitic caves of the Diamantina Plateau, Minas Gerais, Brazil, with a key to the known species
}

\author{
José Paulo L. Guadanuccia, Rafael Fonseca-Ferreira ${ }^{b, c}$, Renner Luiz Cerqueira Baptista ${ }^{d}$ \\ and Denis Rafael Pedroso
}

\begin{abstract}
aDepartamento de Zoologia, Instituto de Biociências, Universidade Estadual Paulista, Rio Claro, Brazil; 'Laboratório de Estudos Subterrâneos, Departamento de Ecologia e Biologia Evolutiva, Universidade Federal de São Carlos, São Carlos, Brazil; 'Pós-graduação em Biologia Comparada, Faculdade de Filosofia, Ciências e Letras de Ribeirão Preto, Universidade de São Paulo, Ribeirão Preto, Brazil; 'Laboratório de Diversidade de Aracnídeos, Departamento de Zoologia, Universidade Federal do Rio de Janeiro, Rio de Janeiro, Brazil; eLaboratório de Aracnologia, Departamento de Invertebrados, Museu Nacional, Universidade Federal do Rio de Janeiro, Rio de Janeiro, Brazil
\end{abstract}

\begin{abstract}
Trechona diamantina sp. nov. is described from quartzite caves in Diamantina, central Minas Gerais State, Brazil. This represents the largest cavernicolous mygalomorph population ever recorded. The new species is the first Trechona recorded from a xeric habitat, namely the Rocky Fields on the Diamantina Plateau. T. diamantina sp. nov. is closely related to $T$. uniformis, both species possessing elongated male and female copulatory organs and both constructing distinct funnel-webs and sheet-webs in quartzite formations. T. diamantina sp. nov. is distinct in possessing less elongated embolus and receptacula seminis. A key for all valid species of the genus is given.
\end{abstract}

http://zoobank.org/urn:Isid:zoobank.org:pub:EB9E66B3-4701-470C-A80D-873E25F52042

\section{ARTICLE HISTORY}

Received 1 February 2016

Accepted 20 May 2016

Online 8 July 2016

\section{KEYWORDS}

Spider; new species; taxonomy; troglophile; hypogean environment

\section{Introduction}

The genus Trechona C.L. Koch 1850 includes medium to large mygalomorph spiders of the family Dipluridae, which are endemic to the Atlantic Forest in Brazil (Pedroso et al. 2008). Following the taxonomic changes proposed by Pedroso et al. (2008), the genus currently comprises three species: T. rufa Vellard 1924, T. uniformis MelloLeitão1935 and T. venosa (Latreille 1932) (World Spider Catalog 2016). The species described so far have been recorded from the states of São Paulo, Rio de Janeiro, Minas Gerais and Espírito Santo (Pedroso and Baptista 2004; Pedroso et al. 2008; Azevedo and Pedroso 2010). However, unidentified specimens have been examined from the states of Bahia, in northeastern Brazil, and Santa Catarina and Rio Grande do Sul, in southern Brazil. Representatives of the genus Trechona are recognised by a well-developed lyra on the prolateral face of the palpal coxae (maxillae). The lyra is 
composed of multiple rows of numerous stiff setae of different sizes and shapes. Setae of the first kind are long and robust, ranging from 15 to $20 \mathrm{~mm}$, with a modified apex, usually club-shaped, and arranged in a wide row. Setae of the second kind are shorter and thinner, with an acute apex, arranged in several series in front of the row of large setae (Pedroso et al. 2008). Trechona species are also characterised by having a body size ranging from 25 to $50 \mathrm{~mm}$ in length, and a transverse-striped pattern on the abdominal dorsum (Raven 1985; Azevedo and Pedroso 2010). Typical Trechona, for example $T$. venosa and $T$. rufa, live in burrows without an aboveground web; at most, there is a veil of silk threads covering the silk-lined entrance of the burrow. T. uniformis, on the other hand, builds a funnel-web running into a burrow or crevice between or under stones. The funnel-web may be relatively long, but usually extends just a few centimetres beyond the entrance of the burrow. Specimens of $T$. uniformis have been collected in holes and crevices in quartzite and granite formations (D. Pedroso and R. Baptista, pers. obs.).

Recently, Guadanucci et al. (2014) reported a troglophile population of an undescribed species of the genus Trechona in a quartzite cave in Diamantina, central Minas Gerais State, Brazil, which is the largest cavernicolous mygalomorph population ever recorded. This species is herein described.

The Diamantina Plateau is located in the Espinhaço Mountain Range, a 1200-km-long series of highlands running in a north-south direction (Saadi 1995) that separates three major biomes in Brazil: Atlantic Forest, Cerrado and Caatinga. The mountain range is characterised by a particular phytophysiognomy named 'Rocky Fields' where temperature and humidity vary considerably and vegetation is typically xeromorphic (Giulietti et al. 1997). Rocky Fields, which are not exclusive to Espinhaço Mountain Range, appear as isolated spots or transitions zones among those three major biomes (Gontijo 2008). Landscape and floristic composition have a great influence on these biomes (Kamino et al. 2008).

During a recent survey carried out on the Diamantina Plateau (Minas Gerais, Brazil) by one of the authors (RFF), a few specimens, including an adult male, of the abovementioned undescribed Trechona species were collected from several caves, thus providing both sexes for the description of the species.

\section{Material and methods}

Specimens from the following institutions (curators given in parentheses) were examined:

MZSP - Museu de Zoologia da Universidade de São Paulo, São Paulo, Brazil (R. Pintoda-Rocha); CAD - Coleção Aracnológica Diamantina, Diamantina, Brazil (J.P.L. Guadanucci).

All measurements are in millimetres and were taken with an ocular micrometer scale. The length of leg articles was measured between the joints in dorsal view. The length and width of carapace, eye tubercle, labium and sternum are the maximum values obtained. Total body length does not include the chelicerae and spinnerets. The number and arrangement of spines follows the terminology of Petrunkevitch (1925). Pictures were taken using a Leica M205C with a Planapo 1.0x lens and an attached DFC 295digital camera. Palpal organs were removed from the cymbium and depicted in 
prolateral and retrolateral views. The vulva was cleared with clove oil and, after examination, pieces of tissue around it were removed with needles.

Abbreviations: AME - anterior median eyes; ALE - anterior lateral eyes; PME - posterior median eyes; PLE - posterior lateral eyes.

\title{
Taxonomy
}

\author{
Family Dipluridae Simon, 1889 \\ Subfamily Diplurinae Simon, 1889 \\ Genus Trechona C.L. Koch, 1850 \\ Trechona diamantina sp. nov.
}

(Figures 1-3; Tables 1-3)

\section{Material examined}

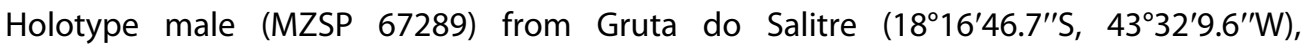
Diamantina, Minas Gerais, Brazil, 1 November 2014, R.F. Ferreira and C.S. Fernandes. Paratypes: 1 female (MZSP 67290) from Lapa do Manéu (18 $\left.16^{\prime} 20.5^{\prime \prime} S, 43^{\circ} 46^{\prime} 57.1^{\prime \prime} \mathrm{W}\right)$, Diamantina, Minas Gerais, Brazil, 19 February 2014, R.F. Ferreira and B.G.O. do Monte; 1 female (MZSP 67291) from Gruta Monte Cristo $\left(18^{\circ} 11^{\prime} 12.5^{\prime \prime} S, 43^{\circ} 47^{\prime} 59.8^{\prime \prime} \mathrm{W}\right)$, Diamantina, Minas Gerais, Brazil, December 2014, T.S. Pires. Other specimens: Diamantina: 1 juvenile

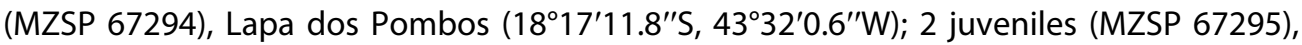
Monte Cristo Cave; 2 juvenile females (CAD 028), from Monte Cristo Cave, J.P.L. Guadanucci, September 2009.

\section{Etymology}

The specific epithet refers to the type locality, the Diamantina Plateau in central Minas Gerais State.

\section{Diagnosis}

Mature specimens of Trechona diamantina sp. nov. can be distinguished from congeners by the light reddish colouration of the carapace and by dark legs, palps and chelicerae in both sexes (Figure 3). The new species is presumably closely related to $T$. uniformis, both possessing a long embolus and elongated receptacula without head or lateral branches, as well as transversal stripes that are almost touching or fused along the median line of the dorsal side of the abdomen. Males differ from those of $T$. uniformis by the piriform tegulum (vs. globular), and by the less elongated embolus (vs. much longer) (Figure 1(d-f)). Females differ from those of $T$. uniformis by the receptacula being less elongated, curved outwards and with a pointed apex (Figure 2(c-d)), in contrast to the very elongated S-shaped receptacula with a rounded apex in $T$. uniformis.

\section{Description}

Male (holotype) (Figure 1; Table 1). Total length: 20.4. Carapace: length 9.5; width 8.2. Eye tubercle: length 0.6; width 1.6. Eye sizes: AME 0.3; ALE 0.5; PME 0.3; PLE 0.4. Labium: length 1.1; width 1.6. Sternum: length 4.0; width 3.7. Each cheliceral furrow 

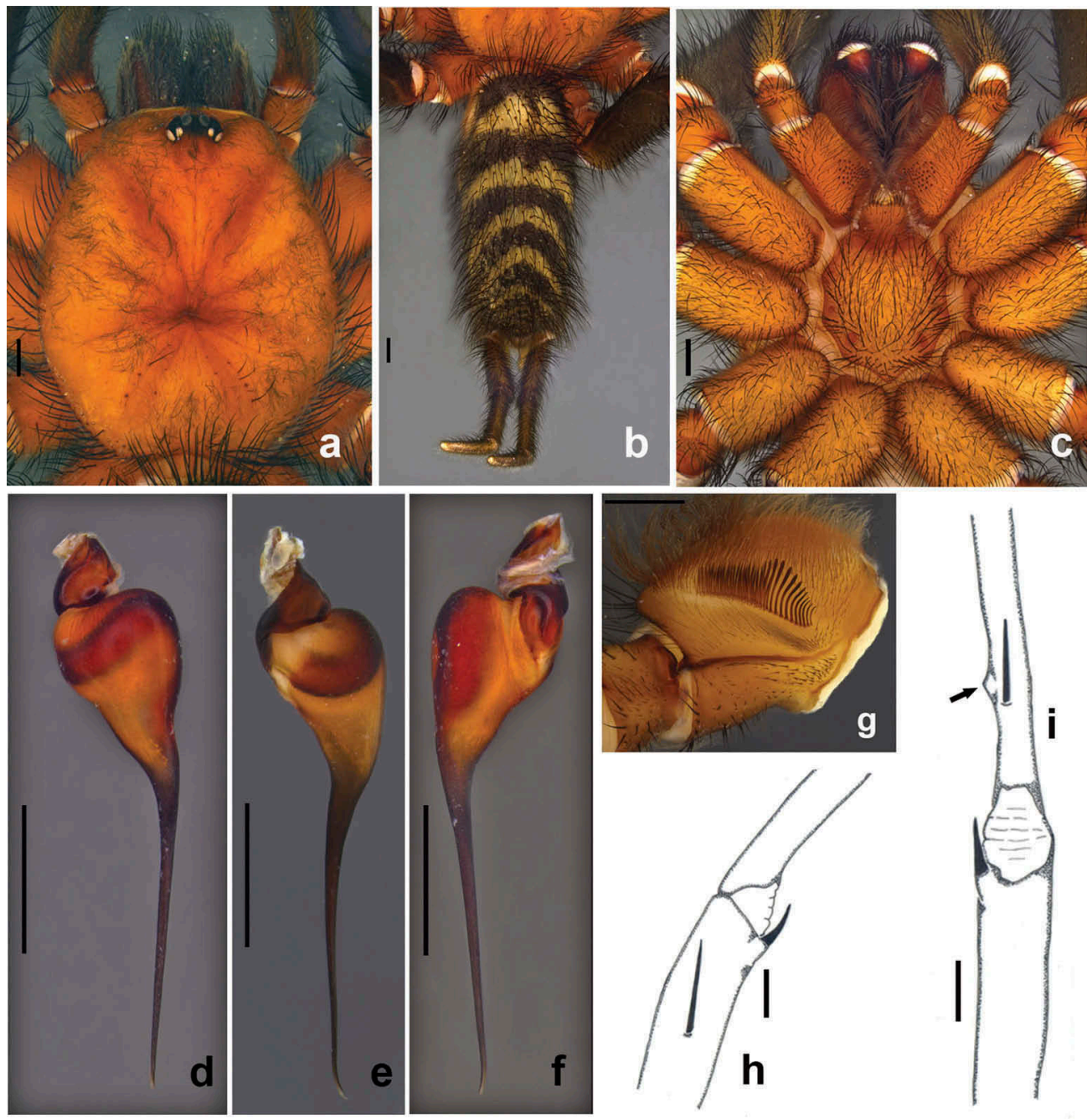

Figure 1. Trechona diamantina sp. nov., male holotype. (a) Cephalothorax, dorsal view. (b) Abdomen, dorsal view. (c) Cephalothorax, ventral view. (d) Palpal organ, retrolateral view. (e) Same, ventral view. (f) Same, prolateral view. (g) Palpal coxa, prolateral view showing lyra. (h) Right tibia and metatarsus I, retrolateral view. (i) Right tibia and metatarsus I, ventral view, arrow pointing to retrolateral nodule. Scale bars $=1 \mathrm{~mm}$.

with 11-12 teeth on prolateral margin; basal article of chelicerae dark. Labium with 1 central cuspule. Palpal coxae (or maxillae) with 40 cuspules on ventral face; lyra composed of 12 large club-shaped setae followed by several rows of smaller setae in distal portion. Sternum rounded, posterior sigillae less than its diameter apart from sternum margin (Figure 1(c)). Spines: all tarsi without spines; palp: femur (d) ap2, patella (p)1, tibia (p) 1-1, (v)2-2-r1; legs: I: femur (d) 2-3-4-3, patella (p) 1, (r) 1, tibia (p) 1-1, (v) 2-2, (r) 1-1-1, metatarsus (p) 1-1, (v) 1-1-1; Il: femur (d) 3-3-3-2, patella (p) 1, tibia (v) 2-2-ap2, (r) 1-1, (p) 1-1, metatarsus (p) 1, (v) 1-1-1-ap1; III: femur (d) 3-3-3-2, patella (r) 1, (p) 1, tibia (d) 1-1, (r)1-1-1, (v) 2-2-ap2, (p) 1-1, metatarsus (d) 

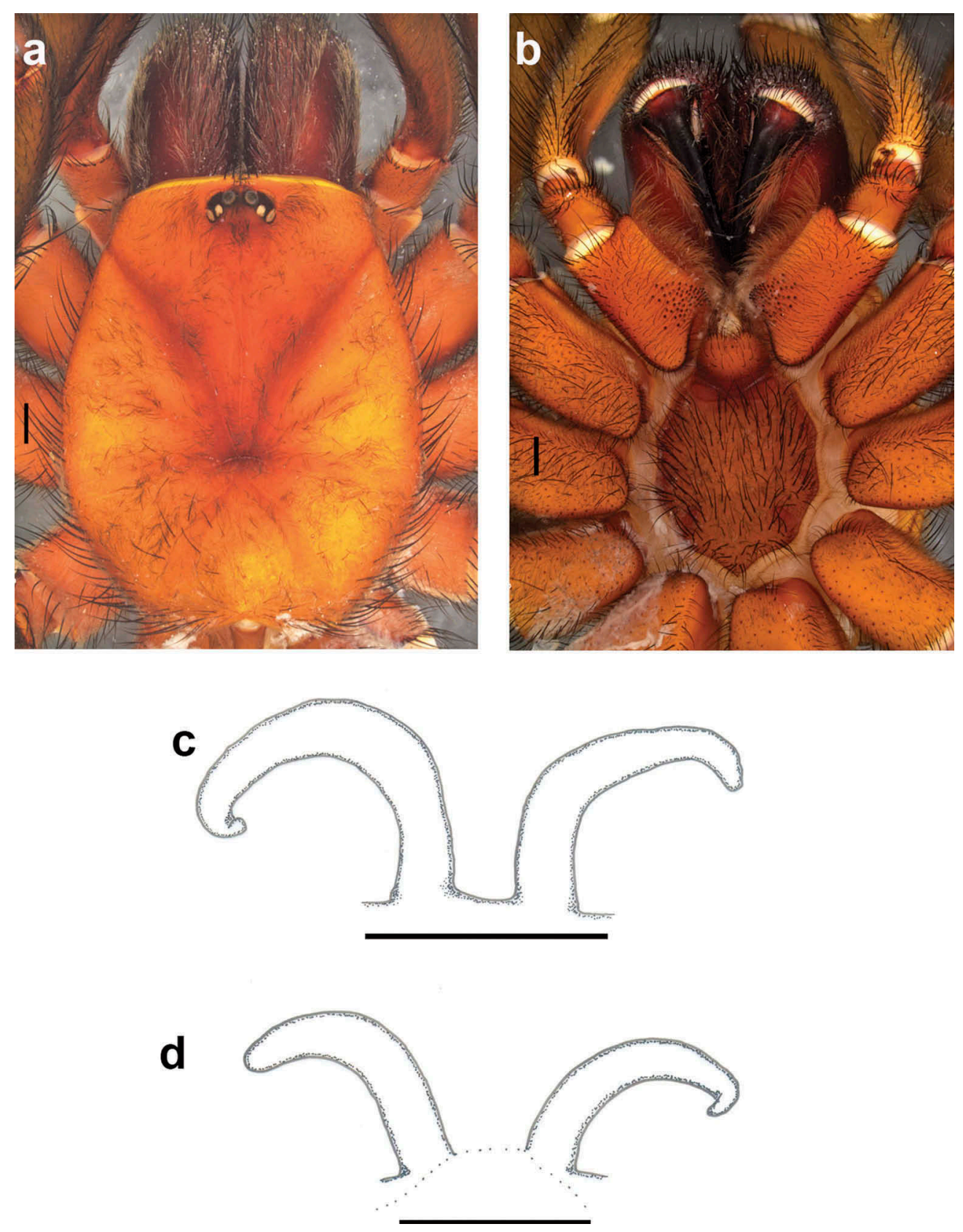

Figure 2. Trechona diamantina sp. nov. (a-c) female paratype MZSP 67,290. (a) Cephalothorax, dorsal view. (b) Cephalothorax, ventral view. (c) Vulva, dorsal view. (d) Vulva, dorsal view, female paratype MZSP 67,291 . Scale bars $=1 \mathrm{~mm}$.

1-1-1-1-ap2, (r) 1-1, (v) 1-1-2-ap3, (p) 1-1-1; IV: femur (d) 3-4-4-2, patella (r) 1, (p) 1, tibia (d) 1-1-1, (r) 1-1, (p) 1-1, (v) 2-2-ap2, metatarsus (d) 1-1-1-2, (p) 1-1-1-1, (r) 1-1, (v) 2-1-1-1-ap3. Carapace light reddish, with few grey setae, fovea tranversal, shallow and narrow, a bit recurved (Figure 1(a)). Anterior eye row straight, 


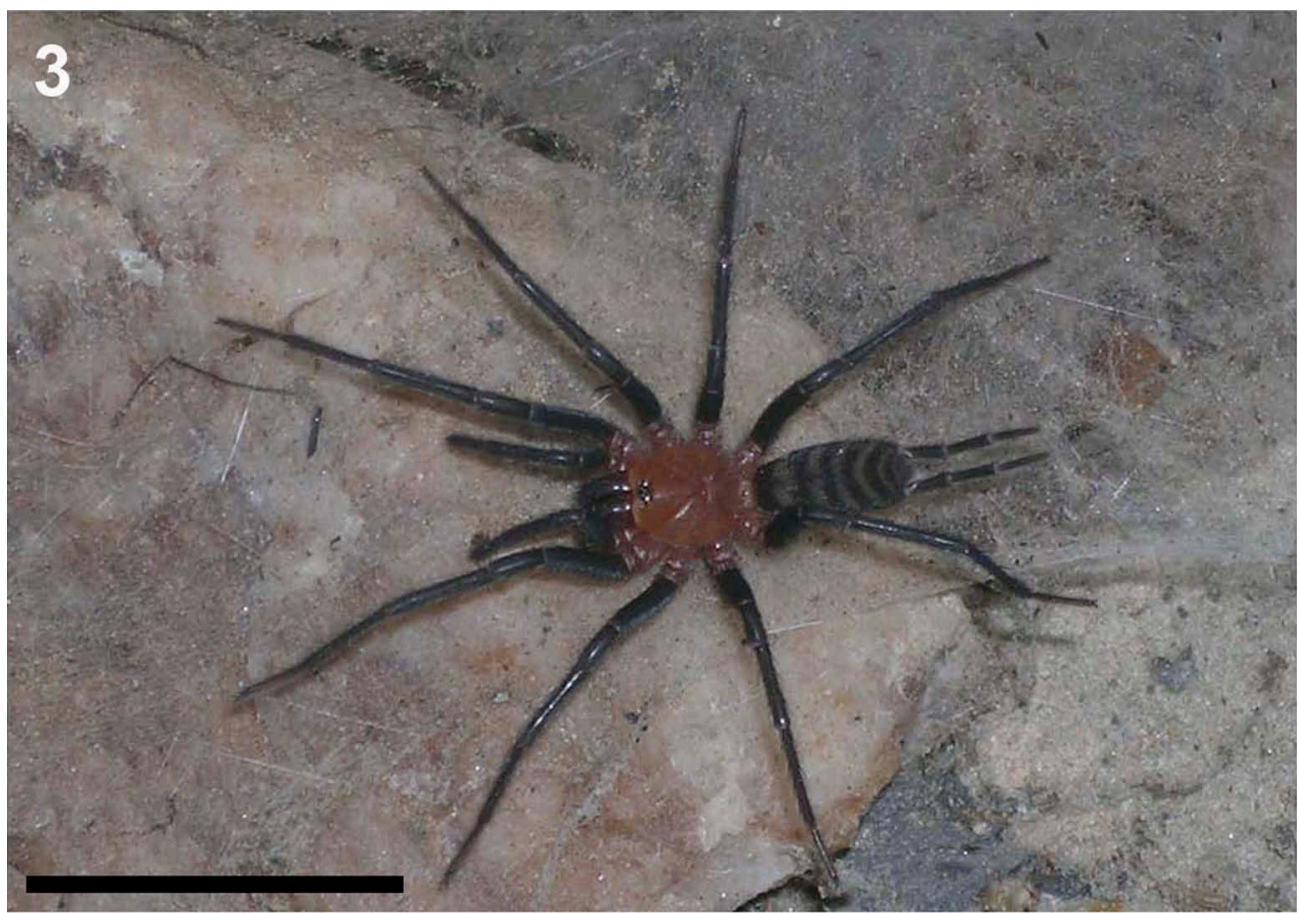

Figure 3. Trechona diamantina sp. nov., female from Monte Cristo cave, Diamantina, Minas Gerais, Brazil, habitus, ventral view. Scale bar $=5 \mathrm{~cm}$.

Table 1. Trechona diamantina sp. nov., male holotype. Measurements of palp and leg articles $(\mathrm{mm})$.

\begin{tabular}{lccccr}
\hline & Palp & Leg I & Leg II & Leg III & Leg IV \\
\hline Femur & 6.5 & 10.8 & 10.5 & 10.1 & 12.1 \\
Patella & 3.1 & 5.4 & 5.0 & 4.2 & 4.7 \\
Tibia & 6.2 & 9.8 & 9.4 & 8.9 & 11.2 \\
Metatarsus & - & 12.2 & 11.0 & 12.2 & 16.6 \\
Tarsus & 1.6 & 7.2 & 7.6 & 6.6 & 8.1 \\
Total & 17.4 & 45.4 & 43.5 & 42.0 & 52.7 \\
\hline
\end{tabular}

Table 2. Trechona diamantina sp. nov., female paratype MZSP 67,290. Measurements of palp and leg articles (mm).

\begin{tabular}{lccccr}
\hline & Palp & Leg I & Leg II & Leg III & Leg IV \\
\hline Femur & 6.9 & 9.6 & 8.9 & 8.3 & 10.9 \\
Patella & 3.6 & 5.1 & 4.6 & 4.3 & 4.5 \\
Tibia & 5.5 & 9.0 & 8.1 & 7.1 & 9.8 \\
Metatarsus & - & 8.9 & 8.7 & 10.3 & 14.2 \\
Tarsus & 5.6 & 5.9 & 6.1 & 5.5 & 6.5 \\
Total & 21.6 & 38.5 & 36.4 & 35.5 & 45.9 \\
\hline
\end{tabular}


Table 3. Trechona diamantina sp. nov., female paratype MZSP 67,291. Measurements of palp and leg articles $(\mathrm{mm})$.

\begin{tabular}{lccccr}
\hline & Palp & Leg I & Leg II & Leg III & Leg IV \\
\hline Femur & 7.6 & 10.1 & 10 & 9.5 & 11.4 \\
Patella & 3.8 & 6.9 & 5.6 & 4.7 & 5.2 \\
Tibia & 6.6 & 10.1 & 8.6 & 8.3 & 10.9 \\
Metatarsus & - & 10.8 & 10 & 11 & 15.4 \\
Tarsus & 6.4 & 7.7 & 7.4 & 7.7 & 8.4 \\
Total & 24.4 & 45.6 & 41.6 & 41.2 & 51.3 \\
\hline
\end{tabular}

posterior one slightly recurved. Male palpal organ long and straight, tegulum pyriform (Figure $1(d-f)$ ). Tibia I with single long megaspine on low spur located at retroventral-apical portion (Figure $1(\mathrm{~h}-\mathrm{i})$ ). Metatarsus I with a small retrolateral nodule at its basal quarter (Figure 1(i), arrow). Paired tarsal claws bipectinated (each with two rows of teeth). Scopulae on ventral side of metatarsi: I 3/4 covered by scopula, II 2/3, III and IV 1/3. Scopulae on ventral side of tarsi: I and II without thick setae, III and IV with a longitudinal band of thick setae. All tarsi pseudosegmented. Legs and palps dark, with light reddish coxae and trochanters. Opisthosoma covered with stiff dark setae; five transversal stripes on dorsum, the two first wider and with a clear notch in the middle, first stripe separated by a tiny median gap, the other stripes fused over the median line of dorsum (Figure 1(b)). Palpal organ (Figure $1(d-f)$ ) more than $50 \%$ of tibia length, c. $1.6 \times$ longer than wide; tegulum piriform, tapering distally and slightly slanted at transition to embolus in retrolateral view; embolus long, almost straight, slowly tapering towards apex in retrolateral view, apex bent retrolaterally in ventral view.

Female (paratype MZSP 67290) (Figures 2(a-c) and 3). Total length: 24.1. Carapace: length 11.0; width 8.9. Eye tubercle: length 0.8; width 1.7. Eye sizes: AME 0.3; ALE 0.6; PME 0.3; PLE 0.4. Labium: length 1.3; width 1.9. Sternum: length 4.7; width 4.1. Each cheliceral furrow with 10-12 teeth on the prolateral margin; basal article of chelicerae dark. Labium with 2 central cuspules. Palpal coxae with approximately 50 cuspules on ventral face; lyra composed of 13 club-shaped setae followed by several smaller setae in distal portion. Sternum similar to that of male (Figure 2(b)). Spines: all tarsi without spines; palp: femur (d) ap2; patella (p) 1; tibia (p) 1-1, (r) 1, (v) 2-2-ap2; tarsus (v) 2; legs: I: femur (d) 1-ap2; patella (p) 1, tibia (p) 1-1, (v) 1-1ap2; metatarsus (v) 1-2-ap1; II: femur (d) ap1; patella (p) 1; tibia (p) 1-1, (v) 1-2-ap2; metatarsus (p) 1, (v) 2-2-ap2; III: femur (d) 2-3-2-2; patella (p) 1, (r) 1; tibia (p) 1-1, (r) 1-1-1, (v) 2-2-ap2; metatarsus (d) 1-1-1-ap1, (r) 2-2-ap1, (p) 1-1, (v) 2-1-2-ap3; IV: femur (d) 3-2-22, patella (p) 1, (r) 1; tibia (p) 1-1-1, (r) 1-1-1, (v) 2-2-ap2; metatarsus (d) 1-1-ap2, (r) $1-2$, (p) 1-1, (v) 1-2-1-2ap3. Carapace and eyes similar to those of male, but fovea seemingly wider, slightly recurved (Figures 2(a) and 3). Paired tarsal claws bipectinated. Scopulae on ventral side of metatarsi: I and II totally covered by scopula, III half and IV 1/4. Scopulae on ventral side of tarsi: I without thick setae, II-IV with a longitudinal band of thick setae. All tarsi pseudosegmented. Colour pattern and setae of abdomen, legs and palps similar to those of male, but first two transversal stripes not fused but almost touching each other in middle line (Figure 3). Vulva composed of two long and narrow receptacula seminis curved outwards, their apices strongly 
tapering, curled, about $5-6 \times$ as long as wide, their bases separated by about their width (Figure 2(c-d)).

\section{Variation}

Female (paratype MZSP 67291) (Figure 2(d); Table 3). Total length: 27.8. Carapace: length 11.3; width 9.3. Eye tubercle: length 1.2; width 2.0. Eye sizes: AME 0.3; ALE 0.5; PME 0.3; PLE 0.4. Labium: length 1.5; width 2.2. Sternum: length 5.0; width 4.4 .

\section{Key to Trechona species}

\section{Males}

1. Dorsum of abdomen with transversal stripes touching or fused with each other along midline, at most with minute gaps between them. Palpal organ $55-80 \%$ of length of palpal tibia, with elongated embolus.

1 '. Dorsum of abdomen with transversal stripes clearly separated, with distinct gaps between them, in some specimens two anterior stripes almost continuous. Palpal organ less than $50 \%$ of length of palpal tibia, with relatively short embolus

2 (1). Carapace brown to dark brown. Palpal organ about $80 \%$ of length of palpal tibia. Bulb relatively short and wider than long. Embolus extremely elongate, approximately $4 \times$ as long as bulb (northeastern São Paulo, southwestern Rio de Janeiro and southeastern Minas Gerais)

T. uniformis

2 '. Carapace light reddish. Palpal organ about $55 \%$ of length of palpal tibia. Embolus moderately elongated, approximately $1.6 \times$ as long as bulb (Diamantina Plateau, Minas Gerais). Trechona diamantina sp. nov.

$3\left(1^{\prime}\right)$. Live or recently preserved specimens with uniformly reddish brown to brownish body. Palpal coxae with up to 33 cuspules. Metatarsus I with area above its basis slightly thinner than rest of article and with retrolateral protuberance clearly visible, placed at same distance from article basis as the retroventral spine of tibia I (Pedroso et al. 2008, fig. 2-3). Bulb globose, with an inner hump; embolus inserted slightly laterally on bulb in frontal view (Pedroso et al. 2008, fig. 5-8) (state of São Paulo) T. rufa

3'. Live or recently preserved specimens with uniformly dark brown to black body. Palpal coxae with at least 40 cuspules. Metatarsus I with area just above its basis much thinner than rest of article and its retrolateral protuberance very small, indistinct, due to the thickening of the whole area around the ventral spine (Pedroso and Baptista 2004, fig. 3-4). Bulb piriform, regularly narrowing towards base of embolus in frontal view (Pedroso and Baptista 2004, fig. 5-8) (states of Rio de Janeiro, Espírito Santo and Minas Gerais).

$T$. venosa

\section{Females}

1. Dorsum of abdomen with transversal stripes contiguous or fused along midline, at 
most with minute gaps between them. Receptacula seminis elongate, without heads (distal widenings) or side branches

1 '. Dorsum of abdomen with transversal stripes clearly separated, with distinct gaps between them, in some specimens two anterior stripes almost contiguous. Receptacula seminis relatively short, each with a distinct head and usually with one long side branch or at least a small knob on its inner side.

2. (1'). Carapace brown to dark brown. Receptacula seminis extremely elongate, S-shaped, continuously tapering to a rounded apex, over $8 \times$ as long as wide; bases of receptacula separated from each other by approximately twice their width. T. uniformis

2 '. Carapace light reddish. Receptacula elongate, curved outwards, in distal fourth abruptly tapering to a pointed apex, about $5-6 \times$ as long as wide; bases of receptacula seminis separated from each other by approximately their width.... Trechona diamantina sp. nov.

$3\left(1^{\prime}\right)$. Live or recently preserved specimens with uniformly dark brown to black body. Abdomen with chevron pattern formed by wide and clearly visible transversal stripes on dorsum and with additional smaller lateroventral stripes placed between dorsal stripes. Cuspules on palpal coxae varying from 50 to 60 . Tarsus III with undivided scopula, rarely with a few black setae in distal portion of article in adult females, but immature specimens with divided scopula (Pedroso and Baptista 2004, fig. 2). Each receptaculum seminis with a relatively small rounded head separated from stalk by a relatively wide and short neck, the latter usually with a distinct outer (ectal) knob (Pedroso and Baptista 2004, fig. 1) T. venosa

3'. Live or recently preserved specimens with uniformly reddish brown to brownish body. Chevron pattern formed by relatively thin and not very contrasting transversal stripes, without additional lateral stripes. Palpal coxae with up to 33 cuspules. Tarsus III with scopula divided by rows of long black setae at least in distal half of article in immature and adult specimens (Pedroso et al. 2008, fig. 1). Each receptaculum seminis usually with a relatively large, egg-shaped head tapering at its inner (ental) side, which is much thinner than the outer side, separated from stalk by a long and thin neck without an outer knob (Pedroso et al. 2008, fig. 4). T. rufa

\section{Discussion}

The webs of Trechona diamantina sp. nov. show a distinct architecture when compared to congeners from typical mesic Atlantic Forest habitats; they are composed of a tubular retreat and a capture sheet-web. The only other Trechona species with a similar web structure is $T$. uniformis (as noted above). The latter species may also be found in quartzite formations, for example in Rio Preto, Minas Gerais State, Brazil (D.F. Pedroso and R.L.C. Baptista, unpub. data), but it was never recorded from xeric habitats. Web architecture, elongated embolus, elongated receptacula seminis without heads or lateral 
branches, and dorsal stripes almost touching or fused along the median line of the abdomen indicate the two species are closely related.

In addition to the previous records of Trechona diamantina sp. nov. in Guadanucci et al. (2014), two caves (Lapa do Manéu and Lapa dos Pombos, all located in Diamantina) are here added to the geographical range. Despite our efforts to collect specimens at several epigean sites of the Diamantina Plateau, we only found these spiders inside caves, including aphotic zones far away from the entrances. Suitable areas outside and near caves were searched thoroughly, without success. The apparent absence of $T$. diamantina sp. nov. from epigean habitats and the additional cave records confirm the troglophile status attributed to this species by Guadanucci et al. (2014). The small number of collected specimens compared to the observation of more than 100 specimens during our field study is also related to the troglophilic status of this species, as any impact on cave populations should be carefully weighted.

According to Guadanucci (2011) and other unpublished data (J.P.L. Guadanucci, pers. obs.), two other mygalomorph species from the Atlantic Forest are also found on the Diamantina Plateau: Oligoxystre mineirum Guadanucci 2011 and Proshapalopus multicuspidatus (Mello-Leitão 1929), both Theraphosidae. Apparently endemic to the Diamantina Plateau, Trechona diamantina sp. nov. is the first record for this genus in the Rocky Fields, adding support to the Atlantic Forest influence in the Espinhaço Mountain Range.

The presence of Trechona diamantina sp. nov. in a subterranean environment, where temperature and humidity tend to be constant (Poulson and White 1969), is particularly interesting. Those spiders were found in the aphotic zone of caves including areas far away from entrances. This species may represent a relatively recent addition to the subterranean fauna of this area, and may have been isolated in caves following climate changes during the Pleistocene. The ability of Trechona diamantina sp. nov. to survive in caves explains its presence in a more xeric environment, when compared to other Trechona species from the Atlantic Forest. It highlights the importance of hypogean habitats for the conservation of biodiversity.

\section{Acknowledgements}

We thank Ricardo Pinto-da-Rocha (MZSP) for providing a repository for the types, Thomás Pires Souto for his great effort in searching for adult males, and Bruno O. do Monte, Camile S. Fernandes and Ives Arnone for their help during field trips and for collecting in caves. RFF thanks the postgraduate programme 'Comparative Biology', University of São Paulo, for financial support, and Maria Elina Bichuette for advice. DRP thanks Capes for a PhD grant.

\section{Disclosure statement}

No potential conflict of interest was reported by the authors.

\section{References}

Azevedo LP, Pedroso DR 2010. Araneae, Dipluridae, Trechona venosa Latreille, 1832: first record for the state of Minas Gerais, Brazil, and distribution map. Checklist. 6:583-584. 
Giulietti AM, Pirani JR, Harley RM. 1997. Espinhaço Range Region. Eastern Brazil. In: Davis SD, Heywood VH, Herrera-Macbryde O, Villa-Lobos J, Hamilton AC, editors. Centres of Plant Diversity: a guide and strategies for the conservation (Vol. 3). The Americas. Cambridge: WWF/IUCN; p. 397-404.

Gontijo BM. 2008. Uma geografia para a Cadeia do Espinhaço. Megadiversidade. 4:7-15.

Guadanucci JPL. 2011. Cladistic analysis and biogeography of the genus Oligoxystre Vellard 1924 (Araneae: Mygalomorphae: Theraphosidae). J Arachnol. 39:320-326.

Guadanucci JPL, Braga PLM, Sá FS. 2014. Aspects of the activity rhythm and population size of troglophilic mygalomorph spiders (Trechona sp., Dipluridae) in a quartzite cave in Minas Gerais, Brazil. J Nat Hist. 49:1-15.

Kamino LHY, Oliveira-Filho AT, Stehmann JR. 2008. Relações florísticas entre as fitofisionomias florestais da Cadeia do espinhaço, Brasil. Megadiversidade. 4:39-49.

Koch CL. 1850. Übersicht des Arachnidensystems. Nürnberg: Heft 5; p. 1-77.

Latreille PA. 1832. Vues génerales sur les araneides à 4 pneumobranches ou quadripulmonaires, suivies d'une notice de quelques especes de mygales inedites et de l'habitation de celle que I'on nomme nidulans. Nouv Ann Mus Hist nat Paris. 1:61-76.

Mello-Leitão CF. 1929. Aranhas do Pernambuco colhidas por D. Bento Pickel. An Acad Bras Ciênc. 1:91-112.

Pedroso DR, Baptista RLC. 2004. Redescription of Trechona venosa (Latreille, 1832) and designation of its neotype (Araneae: Dipluridae). Rev IberAracnol. 10:149-156.

Pedroso DR, Baptista RLC, Ferreira PSF. 2008. Trechona rufa (Araneae, Dipluridae): new status, redescription and neotype designation with notes on the genus. J Arachnol. 36:360-367.

Petrunkevitch A. 1925. Arachnida from Panamá. Trans Conn Acad Arts Sci. 27:51-248.

Poulson TL, White WB. 1969. The cave environment. Science. 165:971-981.

Raven RJ. 1985. The spider infraorder Mygalomorphae (Araneae): cladistics and systematics. Bull Am Mus Nat Hist. 182:1-180.

Saadi A. 1995. A geomorfologia da Serra do Espinhaço em Minas Gerais e de suas margens. Geonomos. 3:41-63.

Simon E. 1889. Voyage de M. E. Simon au Venezuela (décembre 1887 - avril 1888). 4e mémoire. Arachnides. Ann Soc Entomol Fr. 6:169-220.

Vellard J. 1924. Etudes de zoologie. Arch Inst Vital Brazil. 2:121-170.

World Spider Catalog. 2016. World Spider Catalog. Natural History Museum Bern, version 17.0; [cited April 29, 2016]. Available from: http://wsc.nmbe.ch 